\title{
Effect of Choline Chloride on in vitro Rumen Fermentation of Oat Hay based TMR's Varying in Energy Levels
}

\author{
D.K. Gupta, R.S. Grewal*, J.S. Lamba and Simarjit Kaur \\ Department of Animal Nutrition, GADVASU, India \\ Directorate of Livestock Farms, GADVASU, Ludhiana, India
}

*Corresponding author

\begin{abstract}
A B S T R A C T
Keywords

Choline, Rumen fermentation, in vitro gas production

Article Info

Accepted:

18 April 2019

Available Online:

10 May 2019

Present study was conducted to see the effect of different levels $(0,50,75$ and $100 \mathrm{ppm}$ of concentrate) of choline chloride on in vitro fermentation process with rations of different energy content. Two rations were prepared having different energy levels $(1.26 \mathrm{Mcal} / \mathrm{kg}$ $\mathrm{NE}_{\mathrm{L}}$ and $1.50 \mathrm{Mcal} / \mathrm{kg} \mathrm{NE}_{\mathrm{L}}$ ) and both these rations were supplemented with different levels $(0,50,75$ and $100 \mathrm{ppm}$ of concentrate) of choline chloride to see the effect of choline No significant effect of either choline supplementation at different levels was found on any in vitro parameter as compared to control diets with either low or high energy content of ration. On comparison of in vitro results obtained by supplementation of choline chloride irrespective of the level of supplemented choline chloride with low and high energy diets, significant differences in various parameters were obtained at $5 \%$ level of significance. NGP, ME, OMD, \%OMD, TD and short chain fatty acids were significantly higher for high energy diet $(\mathrm{P}<0.05)$ whereas MMP and EMMP were found significantly higher for low energy diet. These results lead to the conclusions that choline does not have any significant role on rumen fermentation process.
\end{abstract}

\section{Introduction}

There are reports (Dyer et al., 1966 and Swingle and Dyer, 1970) which suggest that choline in unprotected form has favorable effect on rumen fermentationFeedstuffs for dairy cattle contain free choline and phosphatidylcholine but content of these compounds in plants is relatively small and their ruminal degradation is extensive (Sharma and Erdman, 1989) so their intestinal supply is not enough to meet tissue requirements for dairy cows. Mean estimates of rumen degradable choline (\%) were 79.4, 84.7, 82.9, 83.8, 98.0, and 98.6 for barley, cottonseed meal, fish meal, soybean meal, choline stearate, and choline chloride respectively (Sharma and Erdman, 1989). Microbial populations in the rumen quickly degrade rationary choline; therefore practical means of increasing choline to the periparturient dairy cows is to feed it in a rumen-protected form (Atkins et al., 1988). Erdman and Sharma (1991) told that rumen protected choline used is very less degraded by rumen microbes and remains stable for 
maximum availability in the intestine of animal. Mohsen et al., (2011) did not find any change in ruminal fermentation on supplementation of ration with RPC at 15 or $30 \mathrm{~g} /$ day. The objective of this study was to see effect of different levels of choline in unprotected form or in the form of Rumen Proctected Choline (RPC) on in vitro fermentation process when supplemented with low $(1.26 \mathrm{Mcal} / \mathrm{kg} \mathrm{NE}$ ) as well as high $(1.50 \mathrm{Mcal} / \mathrm{kg} \mathrm{NE} \mathrm{L})$ energy levels of ration.

\section{Materials and Methods}

In this study two rations were prepared which were isonitrogenous but different in their net energy of lactation $\left(\mathrm{NE}_{\mathrm{L}}\right)$ content. One ration was having low $(1.26 \mathrm{Mcal} / \mathrm{kg} \mathrm{NE}$ ) content while other was having high $(1.50 \mathrm{Mcal} / \mathrm{kg}$ $\mathrm{NE}_{\mathrm{L}}$ ) content. Different concentrations of choline and Rumen Protected Choline (RPC) used in various experiments were $0,500,750$ and $1000 \mathrm{mg}$ per $100 \mathrm{~g}$ of concentrate or equivalent to $0,50,75$, and $100 \mathrm{ppm}$ of concentrate. Composition of the two rations was:

Two rations of different energy levels were supplemented with different concentrations $(0,50,75$, and $100 \mathrm{ppm}$ of concentrate) of choline in $1^{\text {st }}$ experiment and with different concentrations of bypass choline in $2^{\text {nd }}$ experiment. In $3^{\text {rd }}$ experiment different concentrations of either choline or RPC were supplemented with same low energy level of the ration and in $4^{\text {th }}$ expriment different concentrations of either choline or RPC were supplemented with same high energy level of the ration.

\section{In vitro gas production technique}

Thein vitro gas production was done according to Menke and Steingass (1988). The amount of gas produced was used to calculate the ME (Metabolizable energy) value. NDF of the residue was also determined. Total degradable sample(TDS), Organic matter degradability (OMD), Partition factor (PF), \% Organic matter degradability (\% OMD), \% Neutral detergent fibre degradability (\% NDFD), Microbial mass production (MMP), Efficiency of microbial mass production (EMMP), True digestibility (TD) and Short chain fatty acids were calculated according to formulae suggested by (Makkar, 2003). Crude Protein Degradability (CPD) was estimated according to method suggested by Raab et al., (1983). Volaltile fatty acids (VFAs) were estimated using Gas Liquid Chromatography (GLC) technique.

Data were analysed using SPSS software by applying statistical designs including one-way ANOVA and Paired t-test at 5\% level of significance.

\section{Results and Discussion}

When choline was supplemented in unprotected form at different levels $(0,50,75$ and 100)ppm with only low energy diet, no significant difference was observed at 5\% level of significance in any parameter except $\mathrm{PF} \quad(\mathrm{P}>0.05)$. PF value was significantly higher $(\mathrm{P}<0.05)$ at $75 \mathrm{ppm}$ level than $100 \mathrm{ppm}$ level and values at other two levels (0, 50)ppm were similar to $\mathrm{PF}$ values at both these levels. We may conclude from this result that $75 \mathrm{ppm}$ level of choline chloride is more suitable for utilisation of low energy feed by the animal than higher level. But none of the three level used for choline chloride showed significant difference from control with respect to $\mathrm{PF}$ or any other parameter which shows no significant effect of different levels of choline chloride with low energy diet on rumen fermentation process.

When choline at different levels $(0,50,75$, 100) ppm was supplemented along with high 
energy diet in in vitro experiment, no significant difference ( $P>0.05)$ was observed in any parameter at 5\% level of significance. However non significant differences were there and PF, MMP and EMMP values were found maximum for diet supplemented with 100ppm choline. These results show that there is no significant effect of different levels of choline chloride on rumen fermentation process with high energy levels of diet though there may be some non significant increase in the feed utilization at $100 \mathrm{ppm}$ level of choline.

For choline chloride supplemented in different concentrations $(0,500,750$ or 1000$)$ $\mathrm{mg} / 100 \mathrm{~g}$ (or $0,50,75$ and 100)ppm of concentrate and irrespective of the energy level of diet, no significant difference was found for any of the above measured parameters during in vitro study. These results contradict any significant role of choline for rumen microbes as suggested by some scientists (Dyer et al., 1966, Sharma and Erdman 1988). Althoghnon significant changes were there in NGP, \%NDFD, OMD, TD which first increases with choline addition and then decreases at higher choline concentration. EMMP in all the treatment diets was non significantly less than control that avoids any role of choline for microbial growth in the rumen. PF was although maximum for $75 \mathrm{ppm}$ level of choline however at lower or higher levels it is less than control that does not lead to any conclusion. All these results (from Table 1, 2 and 3) suggest that there is no significant effect of choline chloride on rumen fermentation process. These results are in agreement to Rumsey (1985) who found no effect of choline supplementation on rumen fermentation parameters like VFAs, Rumen $\mathrm{pH}$, ammonia and lactic acid isomer changes on all concentrate ration. However these results are in contradiction to the results found in some previous studies (Dyer et al., 1966, Sharma and Erdman 1988) where it was suggested that choline improves microbial performance in rumen.

Table.1 Composition of TMR's used in experiment

\begin{tabular}{|l|c|c|}
\hline Ingredients & Low Energy & High Energy \\
\hline Oat Hay & 40 & 50 \\
\hline Wheat Straw & 20 & -- \\
\hline Maize & 6 & 19 \\
\hline Soya bean Meal & 10.5 & 10 \\
\hline Mustard Cake & 5.5 & 3.5 \\
\hline Cotton seed Meal & 6 & 2.5 \\
\hline D.O.R.B. & 10.5 & 13.5 \\
\hline M.M. & 0.5 & 0.5 \\
\hline Salt & 1 & 1 \\
\hline Chemical Composition, \% DM basis & \\
\hline CP & 16.067 & 16.003 \\
\hline NDF & 29.6 & 23.1 \\
\hline ADF & 36.9 & 30.3 \\
\hline EE & 1.833 & 4.033 \\
\hline ASH & 10.01 & 9.96 \\
\hline Estimated & 1.26 & 1.50 \\
Mcal/Kg & & \\
\hline
\end{tabular}


Table.2 Results of in vitro experiment for diets supplemented with different levels of choline chloride with low energy level $(1.26 \mathrm{Mcal} / \mathrm{kg})$ of diet

\begin{tabular}{|l|l|l|l|l|}
\hline Parameter & Control & $\mathbf{5 0} \mathbf{~ p p m}$ & $\mathbf{7 5} \mathbf{~ p p m}$ & $\mathbf{1 0 0} \mathbf{~ p p m}$ \\
\hline NGP(m) & $74.58 \pm 2.48$ & $72.92 \pm 0.93$ & $74.75 \pm 0.76$ & $74.75 \pm 1.32$ \\
\hline $\begin{array}{l}\text { ME } \\
\text { (MJ/kg of } \\
\text { DM) }\end{array}$ & $8.16 \pm 0.17$ & $8.018 \pm 0.08$ & $8.214 \pm 0.08$ & $8.19 \pm 0.15$ \\
\hline TDS (mg) & $329.37 \pm 2.328$ & $329.67 \pm 1.05$ & $327.34 \pm 1.01$ & $328.79 \pm 2.78$ \\
\hline OMD (mg) & $234.21 \pm 0.51$ & $238.39 \pm 6.69$ & $246.21 \pm 0.87$ & $230.97 \pm 6.12$ \\
\hline PF(mg/ml) & $3.24 \pm 0.07^{\mathrm{ab}}$ & $3.24 \pm 0.04^{\mathrm{ab}}$ & $3.33 \pm 0.001^{\mathrm{a}}$ & $3.04 \pm 0.05^{\mathrm{b}}$ \\
\hline OMD (\%) & $71.37 \pm 0.91$ & $72.16 \pm 2.31$ & $75.02 \pm 0.07$ & $70.74 \pm 1.31$ \\
\hline NDFD(\%) & $57.78 \pm 1.35$ & $58.95 \pm 3.41$ & $63.16 \pm 0.10$ & $56.85 \pm 1.93$ \\
\hline $\begin{array}{l}\text { MMP } \\
\text { (mg) }\end{array}$ & $165.29 \pm 3.97$ & $169.25 \pm 2.41$ & $162.889 \pm 2.53$ & $164.34 \pm 5.11$ \\
\hline $\begin{array}{l}\text { EMMP } \\
\text { (\%) }\end{array}$ & $72.27 \pm 0.24$ & $70.87 \pm 3.69$ & $67.18 \pm 0.11$ & $68.99 \pm 1.41$ \\
\hline TD (\%) & $72.75 \pm 1.17$ & $73.85 \pm 1.75$ & $76.46 \pm 0.46$ & $72.04 \pm 1.69$ \\
\hline $\begin{array}{l}\text { Short } \\
\text { chain FA } \\
\text { (mmol) }\end{array}$ & $1.61 \pm 0.05$ & $1.57 \pm 0.02$ & $1.62 \pm 0.02$ & $1.62 \pm 0.03$ \\
\hline
\end{tabular}

Different superscripts in row vary significantly at $5 \%$ level of significance

Table.3 Results of in vitro experiment for diets supplemented with different levels of choline chloride with high energy level $(1.50 \mathrm{Mcal} / \mathrm{kg})$ of diet

\begin{tabular}{|l|l|l|l|l|}
\hline Parameter2 & Control & $\mathbf{5 0} \mathbf{~ p p m}$ & $\mathbf{7 5} \mathbf{~ p p m}$ & $\mathbf{1 0 0} \mathbf{p p m}$ \\
\hline NGP(ml) & $82.25 \pm 1.00$ & $82.25 \pm 1.32$ & $83.08 \pm 0.17$ & $80.08 \pm 1.36$ \\
\hline $\begin{array}{l}\text { ME (MJ/kg of } \\
\text { DM) }\end{array}$ & $9.31 \pm 0.13$ & $9.34 \pm 0.09$ & $9.40 \pm 0.05$ & $9.07 \pm 0.12$ \\
\hline TDS (mg) & $327.92 \pm 2.54$ & $326.76 \pm 1.16$ & $327.05 \pm 2.10$ & $331.12 \pm 0.77$ \\
\hline OMD (mg) & $269.46 \pm 5.12$ & $270.84 \pm 0.25$ & $271.09 \pm 2.88$ & $272.20 \pm 2.37$ \\
\hline PF(mg/ml) & $3.32 \pm 0.06$ & $3.29 \pm 0.09$ & $3.27 \pm 0.03$ & $3.46 \pm 0.01$ \\
\hline OMD (\%) & $81.66 \pm 0.90$ & $82.74 \pm 0.37$ & $83.27 \pm 1.56$ & $82.06 \pm 0.50$ \\
\hline NDFD(\%) & $65.34 \pm 1.71$ & $67.39 \pm 0.69$ & $68.40 \pm 2.94$ & $66.11 \pm 0.94$ \\
\hline MMP (mg) & $146.97 \pm 4.50$ & $145.81 \pm 1.85$ & $144.26 \pm 2.23$ & $154.94 \pm 3.52$ \\
\hline EMMP(\%) & $56.12 \pm 0.09$ & $53.85 \pm 1.23$ & $52.76 \pm 1.73$ & $58.22 \pm 0.55$ \\
\hline TD (\%) & $82.80 \pm 0.93$ & $83.74 \pm 0.71$ & $83.93 \pm 1.75$ & $82.37 \pm 0.57$ \\
\hline $\begin{array}{l}\text { Short chain } \\
\text { FA (mmol) }\end{array}$ & $1.78 \pm 0.02$ & $1.78 \pm 0.03$ & $1.80 \pm 0.01$ & $1.74 \pm 0.03$ \\
\hline
\end{tabular}


Table.4 Results of in vitro experiment for diets supplemented with different levels of choline chloride, irrespective of the energy level of diet

\begin{tabular}{|l|l|l|l|l|}
\hline Parameter & Control & $\mathbf{5 0} \mathbf{p p m}$ & $\mathbf{7 5} \mathbf{p p m}$ & $\mathbf{1 0 0} \mathbf{p p m}$ \\
\hline NGP(ml) & $78.42 \pm 2.09$ & $77.58 \pm 2.21$ & $78.92 \pm 1.90$ & $77.42 \pm 3.59$ \\
\hline $\begin{array}{l}\text { ME (MJ/kg of } \\
\text { DM) }\end{array}$ & $8.74 \pm 0.28$ & $8.68 \pm 0.30$ & $8.81 \pm 0.27$ & $8.63 \pm 0.21$ \\
\hline TDS (mg) & $328.65 \pm 1.57$ & $328.21 \pm 0.96$ & $327.19 \pm 1.04$ & $329.96 \pm 1.39$ \\
\hline OMD (mg) & $251.83 \pm 10.39$ & $254.62 \pm 9.76$ & $258.65 \pm 7.29$ & $251.58 \pm 12.20$ \\
\hline PF(mg/ml) & $3.28 \pm 0.05$ & $3.26 \pm 0.04$ & $3.30 \pm 0.02$ & $3.25 \pm 0.12$ \\
\hline OMD (\%) & $76.51 \pm 3.11$ & $77.45 \pm 3.20$ & $79.15 \pm 2.47$ & $76.40 \pm 3.32$ \\
\hline NDFD (\%) & $61.56 \pm 2.36$ & $63.17 \pm 2.82$ & $65.78 \pm 1.93$ & $61.48 \pm 2.81$ \\
\hline MMP(mg) & $156.13 \pm 4.90$ & $157.53 \pm 5.42$ & $153.58 \pm 4.43$ & $159.64 \pm 3.48$ \\
\hline EMMP (\%) & $64.19 \pm 4.66$ & $62.36 \pm 5.16$ & $59.97 \pm 4.22$ & $63.06 \pm 3.17$ \\
\hline TD (\%) & $77.77 \pm 2.96$ & $78.79 \pm 2.96$ & $80.20 \pm 2.28$ & $77.21 \pm 3.07$ \\
\hline $\begin{array}{l}\text { Short chain } \\
\text { FA (mmol) }\end{array}$ & $1.70 \pm 0.05$ & $1.68 \pm 0.05$ & $1.71 \pm 0.04$ & $1.68 \pm 0.03$ \\
\hline
\end{tabular}

Table.5 Comparison of high and low energy diets supplemented with choline chloride in vitro for various parameters irrespective of the level of supplemented choline chloride

\begin{tabular}{|c|c|c|}
\hline Parameter & Low energy diet & High energy diet \\
\hline NGP(ml) & $74.25 \pm 0.69^{\mathrm{a}}$ & $81.91 \pm 0.57^{b}$ \\
\hline ME (MJ/kg of DM) & $8.14 \pm 0.06^{\mathrm{a}}$ & $9.28 \pm 0.06^{b}$ \\
\hline TDS (mg) & $328.79 \pm 0.88$ & $328.21 \pm 0.92$ \\
\hline OMD (mg) & $237.45 \pm 0.76^{\mathrm{a}}$ & $270.90 \pm 1.25^{b}$ \\
\hline $\mathrm{PF}(\mathrm{mg} / \mathrm{ml})$ & $3.21 \pm 0.04$ & $3.33 \pm 0.04$ \\
\hline OMD (\%) & $72.32 \pm 0.82^{\mathrm{a}}$ & $82.43 \pm 0.43^{b}$ \\
\hline NDFD (\%) & $59.19 \pm 1.20$ & $66.81 \pm 0.81$ \\
\hline MMP (mg) & $165.83 \pm 1.72^{b}$ & $148.00 \pm 01.85^{\mathrm{a}}$ \\
\hline $\operatorname{EMMP~(\% )~}$ & $69.83 \pm 1.04^{\mathrm{b}}$ & $55.24 \pm 0.90^{\mathrm{a}}$ \\
\hline TD (\%) & $73.78 \pm 0.82^{\mathrm{a}}$ & $83.21 \pm 0.48^{b}$ \\
\hline $\begin{array}{l}\text { Short chain FA } \\
(\mathrm{mmol})\end{array}$ & $1.61 \pm 0.02^{\mathrm{a}}$ & $1.78 \pm 0.01^{b}$ \\
\hline
\end{tabular}

Different superscripts in row vary significantly at 5\% level of significance 
Table.6 Results of in vitro experiment for diets supplemented with different levels of choline chloride with low energy level $(1.26 \mathrm{Mcal} / \mathrm{kg})$ of diet

\begin{tabular}{|l|l|l|l|l|}
\hline Parameter & Group 1 & Group 2 & Group 3 & Group 4 \\
\hline NGP(ml) & $74.58 \pm 2.48$ & $72.917 \pm 0.93$ & $74.75 \pm 0.76$ & $74.75 \pm 1.32$ \\
\hline $\begin{array}{l}\text { ME (MJ/kg } \\
\text { of DM) }\end{array}$ & $8.16 \pm 0.17$ & $8.0178 \pm 0.08$ & $8.21 \pm 0.08$ & $8.188 \pm 147$ \\
\hline TDS (mg) & $329.37 \pm 2.32$ & $329.67 \pm 1.05$ & $327.34 \pm 1.01$ & $328.79 \pm 2.78$ \\
\hline OMD (mg) & $234.21 \pm 0.51$ & $238.39 \pm 6.69$ & $246.21 \pm 0.87$ & $230.97 \pm 6.12$ \\
\hline PF(mg/ml) & $3.24 \pm 0.07^{\mathrm{ab}}$ & $3.24 \pm 0.04^{\mathrm{ab}}$ & $3.33 \pm 0.01^{\mathrm{a}}$ & $3.04 \pm 0.051^{\mathrm{b}}$ \\
\hline OMD(\%) & $71.37 \pm 0.91$ & $72.16 \pm 2.31$ & $75.02 \pm 0.07$ & $70.74 \pm 1.31$ \\
\hline NDFD (\%) & $57.78 \pm 1.35$ & $58.95 \pm 3.41$ & $63.16 \pm 0.10$ & $56.85 \pm 1.93$ \\
\hline MMP (mg) & $165.29 \pm 3.97$ & $169.25 \pm 2.41$ & $162.89 \pm 2.53$ & $164.34 \pm 5.11$ \\
\hline EMMP (\%) & $72.269 \pm 0.24$ & $70.87 \pm 3.69$ & $67.18 \pm 0.11$ & $68.99 \pm 1.41$ \\
\hline TD (\%) & $72.75 \pm 1.17$ & $73.85 \pm 1.75$ & $76.46 \pm 0.46$ & $72.04 \pm 1.695$ \\
\hline $\begin{array}{l}\text { Short chain } \\
\text { FA (mmol) }\end{array}$ & $1.61 \pm 0.05$ & $1.58 \pm 0.02$ & $1.62 \pm 0.02$ & $1.62 \pm 0.03$ \\
\hline
\end{tabular}

Table.7 In vitro parameters for high Energy diet supplemented with choline irrespective of the level of supplemented Choline

\begin{tabular}{|l|l|l|}
\hline Parameter & Control & With Choline Chloride \\
\hline NGP(ml) & $76.50 \pm 1.78$ & $73.75 \pm 1.43$ \\
\hline ME (MJ/kg of DM) & $8.82 \pm 0.14$ & $8.64 \pm 0.11$ \\
\hline TDS $(\mathbf{m g})$ & $329.09 \pm 0.43$ & $330.50 \pm 4.55$ \\
\hline OMD (mg) & $268.33 \pm 1.79$ & $268.04 \pm 1.62$ \\
\hline PF(mg/ml) & $3.50 \pm 0.08$ & $3.58 \pm 0.095$ \\
\hline OMD (\%) & $81.60 \pm 0.64$ & $81.71 \pm 0.33$ \\
\hline NDFD (\%) & $65.21 \pm 1.22$ & $65.42 \pm 0.63$ \\
\hline MMP (mg) & $159.71 \pm 5.16$ & $163.15 \pm 3.98$ \\
\hline EMMP $(\%)$ & $59.58 \pm 2.42$ & $60.86 \pm 1.36$ \\
\hline TD $(\%)$ & $82.20 \pm 0.34$ & $82.21 \pm 0.36$ \\
\hline Short chain FA (mmol) & $1.66 \pm 0.06$ & $1.62 \pm 0.04$ \\
\hline
\end{tabular}

On comparison of in vitro results obtained by supplementation of choline chloride irrespective of the level of supplemented choline chloride with low and high energy diets, significant differences in various parameters were obtained at $5 \%$ level of significance. NGP, ME, OMD, $\% \mathrm{OMD}, \mathrm{TD}$ and short chain fatty acids were significantly higher for high energy diet $(\mathrm{P}<0.05)$ whereas MMP and EMMP were found significantly higher for low energy diet. These results show more proportion of highly degradable substances and less fibre content in high energy diet (Makkar, 2003).

No significant difference was there for any of the above measured parameters between high energy diets supplemented with choline at 5\% level of significance $(\mathrm{P}>0.05)$. However $\mathrm{PF}$, MMP and EMMP were found non significantly higher for choline chloride supplemented diets than control diets that shows some beneficial effect of Choline chloride on microbial 
performance for high energy $\operatorname{diets}(\mathrm{P}>0.05)$ (Table 4-7).

From all these in vitro experiments we may conclude that choline supplementation does not affect rumen fermentation process significantly with either low energy or high energy levels of ration. As it was suggested in many experiments previously (Atkins et al., 1988; Sharma and Erdman 1989) that choline chloride in unprotected form is quickly degraded to a very high extent, so there is no use to supplement choline in unprotected form in the diet of dairy cows.

\section{References}

Atkins K B, Erdman R A, and Vandersall J H. 1988. Dietary choline effects of milk yield and duodenal choline flow in dairy cattle. J. Dairy Sci. 71:109-116.

Bygrave F L and Dawson R M C. 1976. Phosphatidylcholine biosynthesis and choline transport in the anaerobic protozoan Entodenium caudatum. Biochem. Journal 160:481-490.

Dyer I A, Johnson R J, and templeton J. 1966. Are mature cattle getting their choline needs? Feed Age 16, No. 6.

Erdman R A, Shaver R D, and Vandersall J H. 1984. Dietary choline for the lactating cow: possible effects on milk fat synthesis. Journal of Dairy Science 67:410-415.

Erdman R A, and Sharma B K. 1991.Effect of Dietary Rumen-Protected Choline in Lactating Dairy Cows. J. Dairy Sci. 74:1641-1647.

Guozhong $\mathrm{Xu}$, Jun'An Ye, JianxinLiu and Yueying Yu. 2006. Effect of Rumenprotected Choline Addition on Milk Performance and Blood Metabolic
Parameters in Transition Dairy Cows. Asian-Aust. J. Anim. Sci. 19:390-395.

Makkar H P S. 2004. Recent advances in the in vitro gas method for evaluation of nutritional quality of feed resources. In: Assessing Quality and Safety of Animal Feeds. FAO Animal Production and Health Series 160. FAO, Rome, pp. 5588

Menke K H and Steingass H. 1988. Estimation of the energetic feed value obtained from chemical analysis and in vitro gas production using rumen fluid. Animal Research and Development 28:7-55.

Mohsen M K, Gaafar H M A, Khalafalla M M, Shitta A A, Yousif A M. 2011. Effect of rumen protected choline supplementation on digestibility, rumen activity and milk yield in lactating Friesian cows. Journal of Animal Science 44:13-20.

Neil A R, Grime D W, and Dawson R M C. 1978. Conversion of choline methyl group through trimethylamine into methane in the rumen. Biochem. Journal170:529-535.

Rumsey T S. 1985. Effect of choline in all concentrate diets of feedlot steers and on ruminal acidosis. Canadian Journal of Animal Science65(1): 135-146.

Sharma, B.K., and R.A. Erdman.1988a. Abomasal infusion of choline and methionine with or without 2-amino-2methyl-1-propanol for lactating dairy cows.J. Dairy Sci. 71: 2406-2411.

Sharma B K, and Erdman R A. 1989. Effects of dietary and abomasally infused choline on milk production responses of lactating dairy cows. Journal of Nutrition 119:248254.

Swingle R S, and Dyer I A. 1970. Effects of choline on rumen microbial metabolism. Journal of animal science 31:404-408.

\section{How to cite this article:}

Gupta, D.K., R.S. Grewal, J.S. Lamba and Simarjit Kaur. 2019. Effect of Choline Chloride on in vitro Rumen Fermentation of Oat Hay based TMR's Varying in Energy Levels. Int.J.Curr.Microbiol.App.Sci. 8(05): 2238-2244. doi: https://doi.org/10.20546/ijcmas.2019.805.263 